\title{
THE CIRCULAR ECONOMICS OF REVITALIZATION PROCESS OF CONCENTRATED WATER RUNOFF PATHS AND RETENTION RESERVOIRS
}

\author{
Petr MARADA ${ }^{1}$ Jan MAREČEK ${ }^{1}$ Eva KRČÁLOVÁ ${ }^{1}$ Tomáš KRAJÍČEK $^{1}$ \\ Lubor LACINA ${ }^{2}$, IVo HORÁK ${ }^{2}$
1) Mendel University in Brno, the Department of Agricultural, Food and Environmental Engineering, the Czech Rep
2) Mendel University in Brno, the Department of Finance, the Czech Republic

\begin{abstract}
The problem of erosion and degrading soil in an agricultural landscape is very significant. It is most evident in the areas of the concentrated water runoff paths, particularly on the parts of the land blocks, where they are extremely exposed to the form of erosion furrows, through which the water flushes the arable topsoil from the surface. As an effective agri-environmental and climate defence tool, the grassing of these concentrated water runoff paths on arable soil. During this period of climate change, the intensity of heavy rains increases, which causes extreme erosion events. At the same time, it causes unacceptable soil loss from neighbouring land and burdens grassy tracks of concentrated water runoff paths with sediment. This reduces subsequent functionality of concentrated water runoff paths because of a violation of grassland compatibility. The absence of grass in these critical places during repeated torrential rains promotes erosion and subsequent degradation of the soil, as the water drains on it faster than on a properly grassed area. In order to achieve the desired functionality of the measure, for instance, the anti-erosion function, the grassland must be maintained at a reasonable condition, height, and must be above all continuously free from sediment deposits from previous erosion events. For this reason, it is necessary to remove colluvim and accumulated sediment from grassland after erosion events by revitalizing the grassland.

Purpose: The main objective of the paper is to propose a solution to diversification of economic activities - production of different commodities, soil protection, sustainable management and by-products with possible economic effects. Part of the research is the product development from soil sediment, like organic matter demanded by agricultural operations for subsequent recultivation including related economic analysisi of the whole process).

Methodology: Authors analyzed the Rural Development Program and related indicators from the period 2016-2020 and at the same time a literature review of selected demonstration objects. Authors also analyzed the procedure with selected techniques, technologies and agricultural mechanization. We found that no procedure has been yet established for this kind of revitalization, no technique or technology has been developed that would allow the required maintenance operations of these agri-environmental measures and landscape elements. Standard agricultural machinery and mechanization are not functional and suitable. It is necessary to address the problem, which will contribute to the development of the circular economy in this sector and the utilization of erosive sediment. Findings: With suitable machinery and appropriate technology, we would be able to remove the eroded sediment and then re-use it for next possible usage in agricultural sector. However, the current type of machinery that is available today is not apt to take on such a complex task of processing the colluvision taken from the concentrated water runoff paths and retention reservoirs.
\end{abstract}

Key words: Concentrated water runoff path, retention water reservoir, erosion sediment, circular economy, soil protection, agricultural mechanization

JEL category: Q01, Q15, Q16, Q24, O31, O33

https://doi.org/10.11118/978-80-7509-820-7-0182

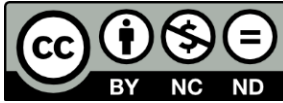




\section{Introduction}

The problem of erosion and degrading soil in an agricultural landscape is very significant. It is most evident in the areas of the concentrated water runoff paths, particularly on the parts of the land blocks, where they are extremely exposed to the form of erosion furrows, through which the water flushes the arable topsoil from the surface. As an effective agri-environmental and climate defence tool, the grassing of these concentrated water runoff paths on arable soil. During this period of climate change, the intensity of heavy rains increases, which causes extreme erosion events. At the same time, it causes unacceptable soil loss from neighbouring land and burdens grassy tracks of concentrated water runoff paths with sediment. This reduces subsequent functionality of concentrated water runoff paths because of a violation of grassland compatibility. The absence of grass in these critical places during repeated torrential rain promotes erosion and subsequent degradation of the soil, as the water drains on it faster than on a properly grassed area. In order to achieve the desired functionality of the measure, for instance, the anti-erosion function, the grassland must be maintained at a reasonable condition, height, must be above all continuously free from sediment deposits from previous erosion events.

For this reason, it is necessary to remove colluvium and accumulated sediment from grassland after erosion events by revitalizing the grassland. The main objective of this paper is to propose a solution to diversification of economic activities production of different commodities, soil protection, sustainable management and by-products with possible economic effects. Part of the research is the product development from soil sediment, like organic matter demanded by agricultural operations for subsequent recultivation including related economic analysisi of the whole process.

\section{Literature review}

We often encounter the problem of erosion in an agricultural landscape (Fiener, P, 2017; Kirkby, M.J. 2010). More than 53\% of the territory of the Czech Republic is covered by an agricultural land (Ministry of Agriculture, 2019). The area of this land - a natural resource, has been degrading for a long time. A significant influence of the intensification of agriculture and the unification of agricultural land management is only deepening the ongoing degradation processes (Slabe-Erker, R, at all. 2019). The most significant soil degradation processes were identified as water erosion, wind erosion (locally), loss of organic matter, soil compaction, soil contamination, reduction of microbial activity in soils, others in the soil are waterlogged soils, accelerated runoff, stopping of agricultural land (Žalud, Z. a et al., 2020; Oostt, van K. at all., 2007). The potential threat for our agricultural land from water erosion in the Czech Republic, expressed by long-term average soil shear $(\mathrm{G})$ is evaluated in Figure 1. It is based on the USLE equation (Wischmeier and Smith, 1978) using vegetation protection factor $\mathrm{C}$ according to climatic regions and expresses values of long-term average soil shear $(\mathrm{G})$. 
Figure 1. Long-term average soil loss $(G)$ in 2019 - potential threat to agricultural agriculture in the Czech Republic from water erosion (source: www.vumop.cz)

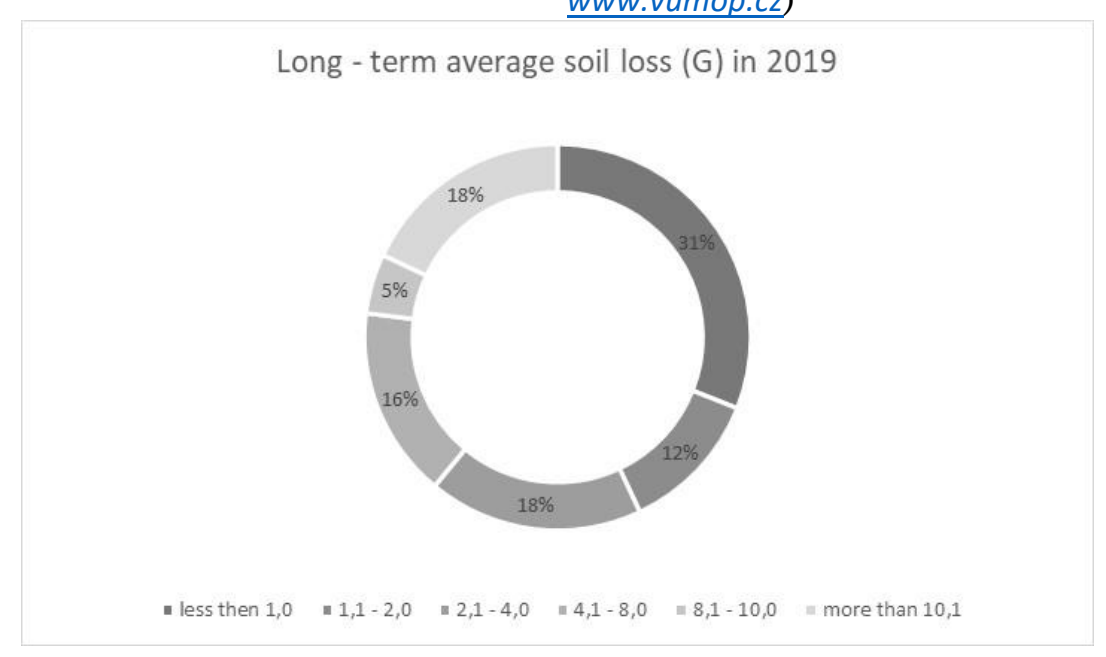

Water erosion is becoming a significant problem in the Czech Republic due to some extreme hydrological phenomena in recent years in terms of soil degradation. Valuable land which is carried to the neighboring lands by concentrated surface runoffs during torrential rains and subsequently transported to the built-up areas of the municipalities, causes damage to property and also enters the hydrographic networks. In water streams and reservoirs, the soil sediments and mixes with a pollution, which makes valuable soil toxic waste that cannot be used for reclamation and it is necessary to getr id off such waste.

Manifestations of erosion occurring on source land in the basin due to surface runoff are divided into surface and groove erosion and erosion causing ephemeral deep grooves in the paths of concentrated surface runoff (LARFEN, J. M. et al. 1985).

In particular, to reduce water erosion, wind erosion and reduce water runoff from parts of land blocks with arable land, the Ministry of Agriculture prefers and supports agri-environmental and climate measures "Grassing of concentrated runoff tracks" and "Grassing and greening of valleys" as the establishment of new landscape elements (Vejvodová A., 2016; MZe, 2020).

Farmers are motivated to create and subsequently manage functional measures; however, appropriate procedures, techniques and technologies are not currently in place for the management and maintenance of these landscape features. Especially for conditions where, after erosion events from the cultivated agricultural land in the vicinity of these grassy areas, the outflowing water transports sediment, which is settled on the grassed area of the measure; this damages the grassland and measures taken with regard to future erosion events and they lose functionality.

In particular, a suitable agricultural technique (or a working tool) in aggregation with available mobile energy means, thanks to which it would be possible to "cut off" alluvial sediment, revitalize the involved grassland, transport the sediment and 
then landfill (collect for subsequent use) without damaging the involved grassland, has not yet been invented (Kumhála, F., 2007). If the erosive sediment is subsequently removed, this happens exceptionally, especially from land parcels and buildings outside the agricultural land (Marada et al. 2010) without further treatment and subsequent targeted use. The issue of landscape lawns, which perform mainly non-productive functions, especially procedures for their restoration and establishment, is addressed most recently in the standards of care for nature and landscape issued by the Nature and Landscape Protection Agency (SPPK C02 007: 2018 Landscape lawns). This document also does not set out procedures for the revitalization and rehabilitation of concentrated water runoff paths after erosion events on which landscape lawns are located.

Therefore, the object of the research in the case study is determine specific characteristics of the eroded sediment and determine potential - the size of areas in the Czech Republic that would require such revitalization. In the next part, we analyze suitable technique for the management of grassy tracks of concentrated water runoff and technology for the management of this raw material and determine possibility to subsequently use eroded sediment in order to analyze economically interesting raw material to be used for the subsequent recultivation of degraded areas (Luc, M. and Szmanda, J.B., 2015; Greblikaité, J at all. 2020).

\section{Methodology}

In solving the problem, we used the methods applied at the Institute of Landscape Water Management, University of Technology, Brno, which has a pedological laboratory for the possibility of processing soil samples (physical properties of soil, analysis of intact soil sample, saturated hydraulic conductivity, etc.). Previous research on the physical properties of soil has been carried out on the basis of available and published methodologies, published, for example, by Dumbrovský et al. (2019), Dumbrovský and Larišová (2016), Dumbrovský et al. (2011).

The researchers based their research on experience with issues related to surface erosion, groove erosion and erosion in ephemeral grooves, which are discussed in Dumbrovský et al. (2020), Sobotková and Dumbrovský (2014), and the utility model Dumbrovský and Sobotková (2012). The procedures presented in these publications have been and will be used in research to determine the parameterization of concentrated water runoff paths, subsequent determination of grass mixtures that are able to withstand the tangential tension of surface runoff, remediation and maintenance of water runoff paths. Furthermore, the experience with the design of anti-erosion protection measures and their implementation in landscaping specified in the methodologies of Doležal, Dumbrovský et al. (2016), Dumbrovský and Sobotková (2015) and in the publication Dumbrovský, Sobotková et al. (2014) which compares the effect of a line protection measure on damage to property in the village. For a successful project solution, grassy valleys were established and maintained in cadastral area of Nenkovice and Šardice (Marada et al. 2019). 
Figure 2. Location of established permanent research areas (symbol $\mathbf{\Delta}$ ) in the cadastral area of Šardice and Nenkovice (symbol $\bullet$ ) in the South-Eastern part of Moravia, the Czech Republic. The gray layer on the map shows the forested areas of the Czech Republic.

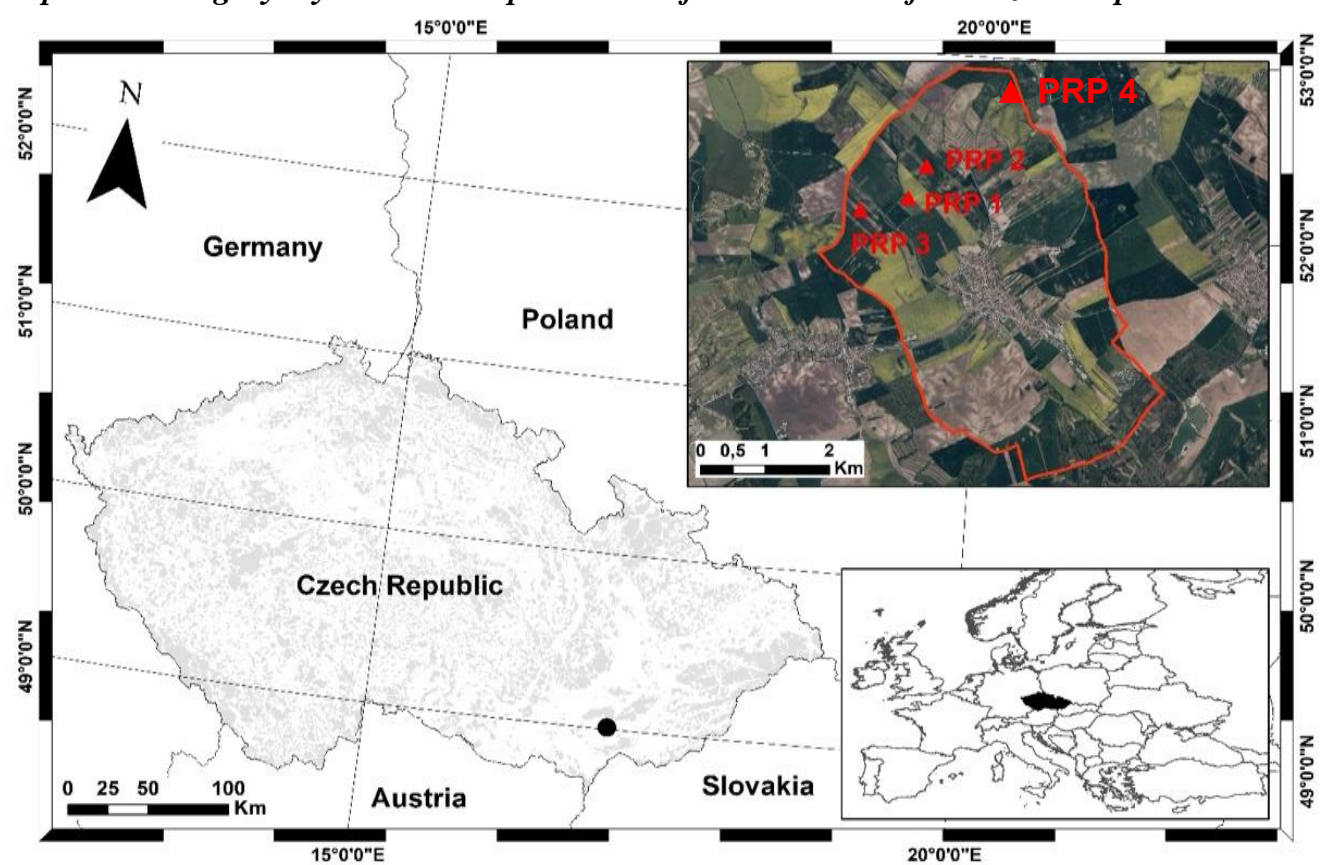

In order to determine the size of areas with the potential for subsequent management, maintenance, removal and subsequent use of erosion sediment, the analytical part of the Strategic Plan of Support of the Common Agricultural Policy for 2021-2027 (Ministry of Agriculture, 2020) and the subsequent plan within the intervention Agrienvironmental and Climate Measures soil „Grassing of the Arable Land“, the available information provided by the State Agricultural Intervention Fund was also used. The Fund also publishes information on the real payments proceeded to farmers for the measures taken.

The Methodology for evaluating the potential of the total amount of colluvisions:

$$
\begin{gathered}
\mathrm{PCMK}=\sum(\text { ZDSO } . \varnothing P M E O) ; \\
\mathrm{ZDSO}=(\mathrm{DSO}+\mathrm{OOP}+\mathrm{OP}+\mathrm{Mo}+\mathrm{Sa}+\mathrm{Vi}+\mathrm{Biop}+\mathrm{KP}))
\end{gathered}
$$

where:

PMEO - permissible erosion risk rate

DSO - acreage of concentrated water runoff paths

Mo - Wetland 
$\mathrm{Sa}$ - Orchard

$\mathrm{Vi}$ - vineyard

Biop - bio-corridor

$\mathrm{KP}$ - landscape element

$\mathrm{OP}$ - protected zone

OOP - protected zone on arable land

Economics of grassed tracks of concentrated water runoff focused on the production of forage and soil-forming substrate

The Methodology for evaluating the economic efficiency of agroforestry systems from the farmer's point of view was used to determine the economics of administration and maintenance of grassed concentrated water runoff paths (Lojka, B. et al. 2020).

NPV scenario without implementation of grassed concentrated runoff water paths:

$$
N P V_{k o n v}=\sum_{t=1}^{T_{p}}\left(q_{t} \cdot c_{t}+S A P S_{t}-v_{t}\right) \cdot h \cdot\left(1+r_{n}\right)^{-t}
$$

where the following means:

$\mathrm{Tp}$... Evaluation time derived from element functionality [year] $\mathrm{q}_{\mathrm{t} . . .}$ Crop yield cultivated in ,, $\mathrm{t}$ " year of crop rotation $[\mathrm{t} / \mathrm{ha}]$ $\mathrm{c}_{\mathrm{t}} .$. Sales market price commodities grown in , $\mathrm{t}_{\text {" }}$ year $[\mathrm{CZK} / \mathrm{t}$ ] SAPS $_{\mathrm{t} . .}$ Subsidy based on area in „t" year [CZK / ha] $\mathrm{v}_{\mathrm{t}}$... Specific spending on crop cultivation in ,t“ year [CZK / ha] $\mathrm{h}$... Total area of land analyzed [ha]

$r_{n} \ldots$ Nominal discount rate [usually $5-10 \%$ ]

NPV scenario with implementation of grassed concentrated runoff water paths:

$$
\begin{gathered}
N \underset{\text { RSO }}{N V_{\text {onv }}}=\sum_{t=1}^{T p}\left[\left(q_{t} \cdot c_{t}+S A P S_{t}-v_{t}\right) \cdot h_{\text {konv }}+\left(Q_{t} \cdot C_{r e f, t}+D O T_{t}-\right.\right. \\
\left.\left.V_{t}\right) \cdot h_{D S O}\right] \cdot\left(1+r_{n}\right)^{-t}(2)
\end{gathered}
$$

Where:

$h_{k o n v} \ldots$ Area for conventional crops [ha]

$Q_{t} \ldots$ Crop yield of substrate in „t“ year [t/ha] 
$C_{r e f, t} \ldots$ Reference price of the soil-forming substrate in „t" year [Kč/t]

$D O T_{t} \ldots$ Subsidy related to area in , "t year [Kč/ha]

$V_{t} \ldots$ grassed concentrated runoff water paths administration and maintenance expenditure in , „“" year [CZK / ha], including the cost of establishing

$h_{D S O} \ldots$ area of grassed concentrated runoff water paths [ha]

There is thus a comparison of the NPV of these two scenarios. Implementation of the grassed concentrated runoff water paths is effective if $N P V_{k o n v, D S O}$ is higher than $N P V_{\text {konv }}$.

If we consider $D O T_{t}=$ SAPSt and yields (in tonnes per hectare) biomass and soilforming substrate and conventional crops for directly proportional to "occupied" area, then evaluation can be simplified to this equation:

$$
N P V_{\text {delta }}=\sum_{t=1}^{T p}\left[\left(Q_{t} \cdot C_{r e f, t}-V_{t}\right)-\left(q_{t} \cdot c_{t}-v_{t}\right)\right] \cdot\left(1+r_{n}\right)^{-t}
$$

If $N P V_{\text {delta }}$ is positive, then, the implementation of the grassed concentrated runoff water paths under the assumptions and purely economic rating is for producer, this is to say farmer, effective.

\section{Analysis of a suitable technique for managing grassed tracks of concentrated runoff and technology for handling this raw materiál}

Machines for earthworks and land reclamation works were evaluated - dozers, scrapers, graders (Tlapák, V., Filip, J. 1986) and subsequently technical and technological requirements for excavators - working tools for decoupling soils eroded sediment from grassland. At the same time, the available methodology for the management and maintenance of similar areas abroad (Water Environment Services (WES) Of Clackamas County: 2020) was analyzed.

\section{Utilization of eroded sediment}

The price of the eroded sediment will be influenced in principle by supply and demand. The prices for Horticultural substrate or soil for lawns, which is commercially available for prices in the 6th month of 2021 at the level of CZK 1,300 can be used as a guide value and basis for valuation $\mathrm{m}^{-3}$.

\section{Results and discusion}

From the available information of the State Agricultural Intervention Fund, it was found that in 20197 applicants were supported in the amount of CZK 956,521 for grassing the concentrated runoff tracks and in 20208 applicants in the amount of CZK 1,000,000 were supported. The annual amount of support is set at 560 EUR / ha of grassland area. The exchange rate for calculating rates for subsidies for which 
a subsidy application was submitted in 2021 applies the exchange rate of 26.242 CZK/EUR.

\section{The total area of grassed tracks of concentrated runoff}

Based on this, we can determine that in 2019, 65 ha of arable land was grassed with support and in 2020 the supported grassed area was increased by 3 ha to 68 ha of from former arable land.

This area, as a potential, needs to be amplified by selected areas of arable land that have been grassed as difficult to cultivate. Furthermore, as an interruption strip dividing the soil blocks and last but not least as protective strips for protected crops (eg. maize). It is also impossible to omit the areas that were greened after complex landscaping as grassed and greened valley and grassy sags.

\section{The potential of the total amount of colluvisions}

Based on the analysis of the Strategic Plan of Support of the Common Agricultural Policy for the period 2021-2027 (Ministry of Agriculture 2020), within the intervention Agri-environmental and climate measure "Grassing of Arable Land", it is considered that in the following years until 2027 will be grassed up to 9848 ha of agricultural land in places of concentrated drainage paths.

Table 1. Planned grassing targeted for soil protection (ha)

\begin{tabular}{|l|l|l|l|l|l|l|}
\hline Year & 2022 & 2023 & 2024 & 2025 & 2026 & 2027 \\
\hline ha & - & 3283 & 4924 & 6566 & 8207 & 9848 \\
\hline
\end{tabular}

It is expected that eroded sediment will accumulate on grassy areas in the amount of at least 5 t.ha-1.year-1 (average value of the permissible degree of erosion risk set in the currently valid anti-erosion decree)

Table 2. Permissible erosion risk rate (PMEO)

\begin{tabular}{|l|l|l|l|}
\hline Characteristics of land & $\begin{array}{l}\text { Depth of } \\
\text { land }\end{array}$ & $\begin{array}{l}\text { Value of the 5th digit of the BPEJ code } \\
\text { (combined soil skeletality and soil depth } \\
\text { code) }\end{array}$ & $\begin{array}{l}\text { Permissible erosion risk } \\
\text { rate }\left(\mathrm{t}^{-h a^{-1}} \cdot \mathrm{year}^{-1}\right)\end{array}$ \\
\hline Deep land & $>60 \mathrm{~cm}$ & $0,2,3$, & 9,0 \\
\hline Semi-deep land & $30-60 \mathrm{~cm}$ & $1,4,7^{*}$ & 9,0 \\
\hline Shallow land & $<30 \mathrm{~cm}$ & $5,6,8^{*}, 9^{*}$ & 2,0 \\
\hline
\end{tabular}

Given the size of the areas that are currently grassed and that will be grassed, the potential for revitalization is and will be significant.

\section{Specification of the eroded sediment}

Analyzes have shown that the technical properties of eroded sediment are most similar to colluvium; these are soils with $A p-A k$ - stratigraphy, arising from the 
accumulation of erosive sediments in the lower parts of the slopes and in the concave elements of the slopes and terrain sags. These soils have not yet been mapped. Defining them will help in assessing the actual erosion.

According to Zádorová (2009), colluvium is a newly introduced soil type, appearing as a separate unit only in some taxonomic systems. Colluvium is caused by the gradual accumulation of humus material displaced from erosively exposed parts of the land. Its occurrence is influenced by the character of the relief - it is located almost exclusively in places of decrease in the carrying capacity of water flowing down the slope, e.g. in concave elements of the slope (these include microrelief depressions, side valleys and falls) and behind terrain obstacles of natural and anthropogenic character (Němeček et al 2001) and especially in the grassy paths of concentrated runoff. During an intensive collapse, the floodplain is often filled with colluvial sediments, leading to the formation of polygenetic soils of fluvialcolluvial character (Houben et al. 2006).

In Czech taxonomy (Němeček et al. 2001) the accumulated horizon is marked Azx (humus anthropic horizon created by layering the material of humus horizons) and its minimum thickness necessary for the identification of a colluvium is $0.25 \mathrm{~m}$ (i.e. together with the Ap horizon with an average depth of $0,25 \mathrm{~m}$ is a $0.5 \mathrm{~m}$ thick humus horizon). According to the Czech taxonomic system, it would be possible to denote this layered, mineral horizon as $\mathrm{Bz}$ or $\mathrm{Cz}$ (Němeček et al. 2001).

Design of suitable techniques and technologies for handling this raw material, for which subsequent use is offered

The most suitable and usable technique for further development appears to be a universal tractor machine on a wheeled chassis with a large wheelbase, manufactured in a two-axle design with the aim of removing sediment and then moving it from the land and folding it to a designated place for transport. The mechanization with the lowest possible operating weight will be selected. The wheelbase between the front and rear axles ensures favorable conditions for the accuracy of the work tool and the possibility to manipulate it in the middle of the machine and outside it. The disadvantage is the large turning radius and small maneuverability of the machine (Vaněk, A. 2003). These machines are designed for surface movement of soils and subsequent revitalization of grassed DSO. In traffic construction, they are mainly used for removing topsoil, modifying the ground plan, spreading the material and creating embankments and ditches. Modification of the working tool and the tool for material transfer (body, transporter) will be the subject of the following research and development. 

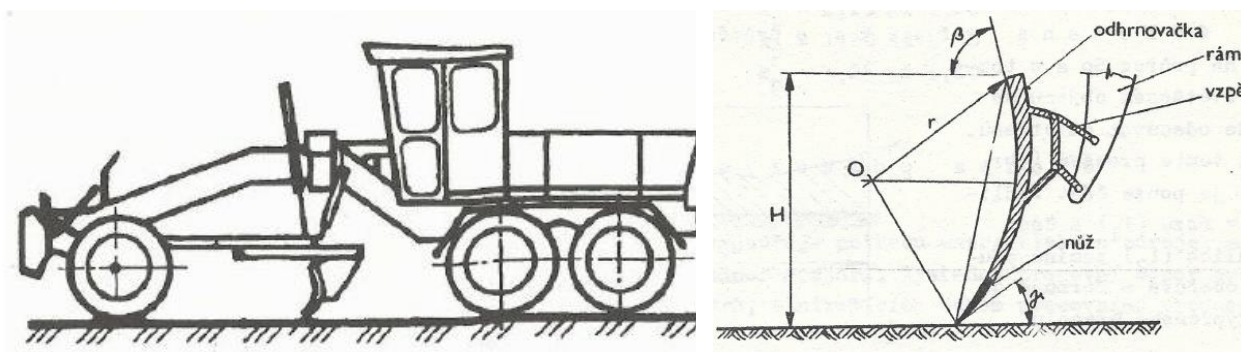

Figure 5. A universal tractor machine on a wheeled chassis with a large wheelbase, manufactured in a two-axle design

Figure 6. The radius of curvature (r), the cutting angle $(\gamma)$, the rolling angle $(\beta)$ and the position of the blade in the ground section ( $\alpha$ ) will play an important role in the design and development of the working tool - blade. (nůz̆ = blade, vzpěra $=$ strut, rám = frame, odhrnovačka = flail mower)

For the subsequent use of the removed eroded sediment, it will be essential to develop a conveyor on which the "cut" erosion sediment will be loaded immediately. It is realistic to use the system used in scrapers, with the condition that the machine will be very light with regard to the specific gravity of erosive sediment, which will make it impossible to use commonly used mechanization.

\section{Economics of grassed tracks of concentrated runoff focused on the production} of forage and soil-forming substrate

Thanks to the establishment of a grassy path of concentrated water runoff, sustainable management can be expected with savings in the costs of damage caused by erosion and an increase in revenues related to the production of biomass and soilforming substrate. This measure is expected to diversify revenues (revenues from the production of soil-forming substrate, which will be generated from the raw material of eroded sediment and from the production of biomass and related agricultural production) and therefore, the long-term goal of increasing overall revenues. In the economic decision-making of farmers, whether and, if so, which measures to put in place in order to prevent and minimize erosion, in the current conditions, the primary activity of agricultural production of biomass intended for food, feeding and other activities remains a complementary function for farmers and their economy. The combination of conventional agriculture with other production associated with the grassing of concentrated runoff pathways leads to a partial reduction in land area for crops intended for biomass production for food, feed and energy transformation), thus reducing the economic effect of conventional crops. The area of grassed concentrated runoff path (DSO) s is used for by-products with 
possible economic effects (e.g. from the sale of a by-product - biomass, soil-forming substrate, etc.).

Side activities are also interesting from an economic point of view, because in addition to the effect from the sale of biomass and substrate brings other qualitative and quantitative effects such as:

- Diversification of economic activities - production of different commodities is produced which are bound to different markets;

- Potential improvement in cash flow producer, eg. In the case of biomass and substrate production, together with traditional crops, producer has a significant cash flow throughout the year, besides the harvest of the main (conventional) commodity;

- Keeping the quality and consumption of land directly determines not only the price of the land, but can also positively affect revenues in the neighborhood of grown crops.

Analysis of economic efficiency of administration and revitalization of grassed drains of concentrated drains can be done from two views, and:

1. From the procuder's point of view - farmer's perspective, which is primarily interested in the overall economic efficiency of land use, which is available for growing activities, it primarily does not take into account any other non-production (societal) effects (see above) from the implementation of the grassy concentrated runoff water paths, if they do not bring direct economic benefits;

2. From a wider systemic view where other items in the economic evaluation of the grassy concentrated runoff water paths may be reflected in the form of awards of non-production functions of the grassy concentrated runoff water paths. Only these two scenarios are solved in case study. Benefits, according to the point two (systematical aspects), however, can serve as an argument platform for any justification for the introduction of an additional grassy concentrated runoff water paths economic support, such as subsidies.

Economic effectiveness of the grassy concentrated runoff water paths administration and maintenance

In the case of economic evaluation of grassy concentrated runoff water paths (combination of a classical agriculture with the management and maintenance of grassland and sediment), the economic benefits can be evaluated by three approaches:

- Analysis of economic efficiency of stands with a goal (for entered inputs awarded by market

Price and size of biomass production or soil-forming substrate) Find a minimum price

- Production created from erosion sediment, which will provide the producer to the required economic effect in the form of revenue from the initial investment in its discount 
- Analysis of the economic efficiency of stands with the attentive possibilities of land use - typically for conventional agricultural production. In the event of an analysis of the economic efficiency of grassy concentrated runoff water paths, the second approach is used; The effect of the implementation of secondary activity (sale of biomass and soil-forming substrate) is analyzed on the economic efficiency of the total use of the land. Conventional (classical) agricultural production is considered primary production, other activity - e.g. biomass production, soil-forming stratium from grassed tracks - is then considered as secondary production. The substrate production is not a minimum price, but the reference price of the commodity is used. For the specified expenditure associated with the implementation of this secondary activity, the amount of production and its valuation of the reference price, the economic effect is determined from this secondary production and compared with the effect that should implement conventional production on the area used for plant growing.

\section{Economic evaluation of grassed concentrated runoff water paths}

- In particular, the assumptions based on the general methodology of the economic evaluation of the biomass and soil-forming substrate are used to create the Economic Efficiency Method.

- Agricultural land is contemplated that does not have restrictions on both conventional crop production and grassed concentrated runoff water paths cultivation;

- Considering the possible different business risk of conventional agricultural production and secondary activities associated with the implementation of grassed concentrated runoff water paths;

- The evaluation is based on the simulation of cash flows related to conventional agricultural productions and secondary production and on the calculation of net present value - NPV;

- Engraved grassed concentrated runoff water paths assumes implementation of activities with a longer period of duration than one year, and therefore economic evaluation is carried out over the duration of this secondary economic activity, eg. In the event of the implementation of grassed belts, the comparison is carried out for the expected time of the element or restoration of grassland at least 5 years;

- For conventional agricultural production is expected to rotate (alternative) crops according to the recommended consecutive procedures;

- The evaluation is carried out when respecting standard market conditions - all activities are valued at market prices - eg individual agrotechnology;

- The evaluation is carried out in normal (nominal) prices, cost escalation of cost entries according to average long-term inflation (appropriate price index - prices of industrial and agricultural services, etc.);

- Income tax (relevant for the agrarian sector) is assumed, grassed concentrated runoff water paths consolidation with other activities of the farm is not considered - The time value of money (in analyzing and calculations based on NPV) is expressed by a nominal discount (including inflation); 
- If the subsidy is granted, the model is taking them into account.

If we apply the above principles of grassed concentrated runoff water paths based on the combination of grassed concentrated runoff water paths agricultural production and maintenance, including biomass production and the production of the soil-forming substrate, this evaluation is based on the comparison of the economic efficiency of two variants:

- Land use variants without landscaped grassed concentrated runoff water paths only agricultural production with crop rotation; The evaluation time is equal to the functionality of grassed DSO;

- Soil use variants with a cloudy grassed concentrated runoff water paths - on the desktop, which remains dedicated for conventional production is applied to the same rotation of crops as in the case without grassed concentrated runoff water paths implementation.

The hydrological regime - water balance is also significant. The breakdown of the soil block part of the grassed valley or grassed concentrated runoff water paths may also have a positive impact on the conventional crop yields (e.g., improving microclimatic conditions, increasing flood and dry resistance, reduction of temperature fluctuations and evaporation, limitation of soil erosion, etc.). However, in particular, there are significant non-productive benefits that have not yet been awarded and not appreciated and their contribution is considerable to environmental, but also long-term sustainability of management and securing of soil fertility in the evaluation of grassed concentrated runoff water paths. Non-productive functions of grassed concentrated runoff water paths are also the main reason why they are supported by subsidies. The aim is to protect the land, increase the ecological stability of the landscape and also to prevent a reduction of revenue, as is the case for agroforestry, the forming substrate may yield the required returns to farmer and a society on the whole.

\section{Conclusions}

For this specific type of farming - revitalization has not yet been established. Functional and systematic procedure, special technique or technologies have not yet been developed which would allow the required operations of administration and maintenance of these agri-environmental measures and landscape elements. Standard agricultural machinery, machines used for earthworks and usable mechanization are not functional and appropriate. Not only for this reason, it is necessary to address the problem that will contribute to the development of the circular economy in this sector with the aim of applying the eroded sediment as a significant raw material usable to revitalize the damaged areas or as a substrate used in horticulture and related fields. Research should be subsequently aimed at developing a product with clear parameters, its specifications and valuation so that its production is interesting for manufacturers and requested by the farmers or other agricultural land users. Design of suitable techniques and technologies for handling this raw material for which subsequent use is offered. The implementation of design 
and development is based on the principles specified in the standard CSN EN ISO 9001: 2016. During the planning of design and development, the following will be determined, in accordance with the created project:

- design and development stages,

- the examinations, verifications and validations that are appropriate to perform at each stage of the design and development, and

- specify the responsibilities of the researchers and the powers of design and development.

Inputs related to the requirements for grassland management and care processes will be identified and the product being developed is identified and records will be maintained. These inputs will be included:

- requirements for the functionality of work tools,

- applicable legal and regulatory requirements,

- information derived from previous similar proposals, and

- other requirements that are essential for design and development.

\section{References:}

1. Dumbrovský, M., Larišová, L., Sobotková, V., Kulihová, M. (2019), Comparison of Different Texture Analysis for Soil Erodibility Calculations of Loamy and Sandy-Loam Soils in Moravian Regions, Acta Universitatis Agriculturae et Silviculturae Mendelianae Brunensis, Brno vol. 67, no. 2, p. 383-393. ISSN: 1211-8516. https://doi.org/10.11118/actaun201967020383

2. Dumbrovský, M., Larišová, L. (2016), The Influence of Different Technologies of Soil Processing on Infiltration Properties of Soil in the Cambisols Area of the Opava District, Acta Universitatis Agriculturae et Silviculturae Mendelianae Brunensis, Brno. 64, 1495 1505. https://doi.org/10.11118/actaun201664051495

3. Dumbrovský, M., Kameníčková, I., Podhrázská, J., Pavlík, F., Sobotková, V. (2011), Evaluation of soil conservation technologies from the perspective of selected physical soil properties and infiltration capacity of the soil, Acta Universitatis Agriculturae et Silviculturae Mendelianae Brunensis, Brno. vol. 59, 37-48. https://doi.org/10.11118/actaun201159010037

4. Dumbrovský, M., Drbal, K., Sobotková, V., Uhtová, J. (2020), An approach to identifying and evaluating the potential formation of ephemeral gullies in the conditions of the Czech Republic. Soil and Water Research, vol. 15, no. 1, p. 38-46. ISSN: 18059384. https://doi.org/10.17221/231/2018-SWR

5. Dumbrovský, M., Sobotková, V., et. al. (2012), Equipment for volumetric quantification of water erosion [utility model] CZ23499 U1. 2012.

6. Doležal, P., Podhrázská, J. Dumbrovský, M., Karásek, P., Martének, J., Kučera, J., Konečná, J., Pochop, M., Toman, F. (2016) Methodical instructions for performing selected activities in the process of landscaping. Certification at State Land Office CZ.

7. Dumbrovský, M., Sobotková, V. (2015), Solution of surface technical anti-erosion measures in the process of landscaping, Certification at SPU ČR, Prague.

8. Dumbrovský, M., Sobotková, V., Šarapatka, B., Chlubna, L., Váchalová, R. (2014), Cost-effectiveness evaluation of model design variants of broad-base terrace in soil erosion control. ECOLOGICAL ENGINEERING, vol. 68, no. 2014, p. 260-269. ISSN: 0925-8574. https://doi.org/10.11118/actaun201462010191 
9. Fiener, P. (2017), Erosion control in agriculture. WASSERWIRTSCHAFT 107 (11), pp.39-42. https://doi.org/10.1002/esp.1796

10. Greblikaité, J. at all. (2020): Management Theory and Studies for Rural Business and Infrastructure Development, eISSN 2345-0355. 2020. Vol. 42. No. 3: 235-247 DOI: https://doi.org/10.15544/mts.2020.23

11. Houben, P., Hoffman, T., Zimmermann, A., Dikau, R. (2006), Land use and climatic impacts on the Rhine system (RheinLUCIFS): Quantifying sediment fluxes and human $\begin{array}{llll}\text { impact with available data. CATENA 66: } 42-52 & \end{array}$ http://dx.doi.org/10.1016/j.catena.2005.07.009

12. Kirkby, M.J. (2010), Distance, time and scale in soil erosion processes, Earth Surface Processes and Landforms, 10.1002/esp.2063, 35, 13, (1621-1623). https://doi.org/10.1002/esp.2063

13. Kumhála, F. (2007), Agricultural technology: machinery and technologies for crop production, Czech University of Life Sciences ,Prague, 2007. 426 s. ISBN 978-8021317-01-7.

14. Larfen, J. M. et al. (1985), Effect of tillage systems on concentrated flow erosion. Soil Conservation and Productivity, p. 3-8.

15. Lojka, B., Martiník, A., Weger, J., Houška, J., Doležalová, H., Kala, L., Szabó, P., Kotrba, R., Krčmářová, J., Chládová, A., Vávrová, K., Jobbiková, J., Ehrenberberová, L., Snášelová, M., Králík, T. (2020), Establishment of agroforestry systems on agricultural land, agroforestry; subsidy titles; economical evaluation; legislation; agricultural land, Certificated Methodology (NmetC), ČZU v Praze, ISBN 978-80-2133061-0

16. Luc, M., and Szmanda, J.B. (2015), Renaturalized and Recultivated Landscapes as a Result of Sustainable Landscape Management. Landscape Analysis and Planning: Geographical Perspectives. Landscape Analysis and Planning: Geographical Perspectives , pp.271-292. https://doi.org/10.1007/978-3-319-13527-4_16

17. Marada, P., Havlíček, Z., Krčálová, E., Skládanka, J. (2010), Agri-environmental management - a prerequisite for successful care of farmers for nature and landscape. 1st ed. Mendel University in Brno, Brno. ISBN 978-80-7375-415-0.

18. Marada, P., Podhrázská, J., Dumbrovský, M., Šarapatka, B., Suchý, P., Straková, E., Vala, Z., Havlíček, Z., Erber, A., Cukor, J. (2018), Methodology for management and maintenance of landscape elements. Certificated Methodology. ISBN 978-80-7509-6159. Certificate number 13/2018-SPU/O

19. Ministry of Agriculture. (2020), Strategic plan for the support of the Common Agricultural Policy for the period 2021-2027 for the Czech Republic. Available at: http://eagri.cz/public/web/file/661117/SP_SZP_verze_rijen_2020_pro_web.pdf. Retrieved: [2020-11-20].

20. Ministry of Agriculture. (2020), Report on the State of Agriculture of the Czech Republic for 2018, "Green Report". Available at: http://eagri.cz/public/web/file/648258/Zelena_zprava_2018.pdf. Retreived: [2020-1120]

21. Němeček, J., et al. (2001), Taxonomic classification system of soils in the Czech Republic. Academia, Prague.

22. Oostt, van K. et al. (2007), The Impact of Agricultural Soil Erosion on the Global Carbon Cycle. SCIENCE, Vol 318, Issue 5850, pp. 626-629. doi: 10.1126/science. 1145724

23. Slabe - Erker, R. at all. (2019): Effects of the European common agricultural policy on preserving biodiversity: farmland birds in Slovenia.EUROPEAN COUNTRYSIDE, Volume 11. Issue 3, page 281 - 297. DOI: https://doi.org/10.2478/euco-2019-0018

24. Sobotková, V., Dumbrovský, M. (2014), The new volumetric approach for field measurements of rill erosion. Abstract Book - 9th International Soil Science Congress 
on "The Soul of Soil and Civilization”. Samsun, Turkey: Pazar Mah. p. 243-243. ISBN: 979-605-63090-21.

25. SPPK C02 007. (2018) Landscape lawns (standard of care for nature and landscape AOPK CR, series C, ÚSES and landscape elements).

26. Tlapák, V. and FILIP, J. (1986), Machines for earthworks and reclamation works: (instructions for exercises), University of Agriculture, Brno.

27. Vaněk, A. (2003), Modern machinery and earthmoving technology, Academia, Pragu, ISBN 80-200-1045-9.

28. Vejvodová, A. (2016), Grassing of concentrated runoff paths - information material for farmers, Prague : Ministry of Agriculture, ISBN 978-80-7434-304-9.

29. Water Environment Services (WES) Of Clackamas County. (2020), The Erosion Prevention and Sediment Control Planning and Design Manual, Oregon.

30. Wischmeier, W. H., SMith, D. D. (1978), Predisting rainfall Erosion Losses - A Guide to Conservation Planning. Agr. Handbook No. 537, U.S. Dept. Of Agriculture, Washington, D.C.

31. Zádorová, T. (2009), Colluvium - their characteristics and problems of area delimitation in selected areas of the Czech Republic, Dissertation thesis, Prague, Charles University.

32. Žalud, Z., Trnka, M., Hlavinka, P., et al. (2020), Agricultural drought in the Czech Republic - development, impacts and adaptation, Prague, Agricultural union CZ, ISBN 978-80-88351-02-3. 